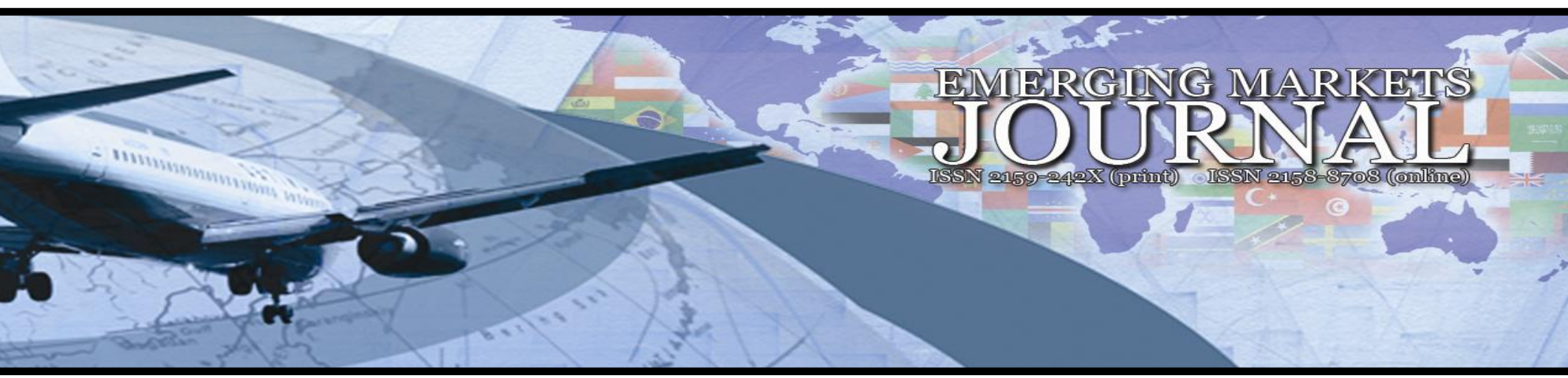

\title{
The effect of relationship marketing on customers' loyalty (Evidence from Zemen Bank)
}

\section{Cherinet Boke Chakiso}

Lecturer, Debre Berhan University, College of Business and Economics, Ethiopia | e-mail: chrnt.b@gmail.com

Volume 5 No 2 (2015) ｜ＩSSN 2158-8708 (online) ｜ DOI 10.5195/emaj.2015.84 | http://emaj.pitt.edu |

\section{Abstract}

Every firm without good marketing team and strategies is bound to fail. In order to be competitive and profitable in the industry, bankers should acquire and retain profitable customers. Definitely this is done with relationship marketing. Relationship marketing is a philosophy of doing business, a strategic orientation that focuses on keeping and improving current customers rather than acquiring new customers. The aim of this study is to investigate the influence of relationship marketing underpinning son

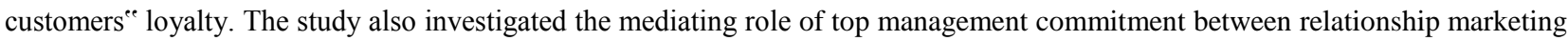
and customerse loyalty. The study is based on information collected from both primary and secondary sources of data. The sample for this study is taken from customers of Zemen Bank in Addis Ababa. Data analyses were done using frequencies, percentages, means, standard deviations, cross-tabulations, and tables followed by discussions. Moreover, inferential statistics of bivariate correlations and simple as well as multiple regressions were used. Findings of this study reveal that there is a significant and strong correlation between relationship marketing and customerse loyalty. Moreover, the study reveals that there is significant effect of trust, commitment, communication, and gratitude on predicting customers' loyalty. Of these relationships, gratitude emerged as the strongest factor which influences customers' loyalty while conflict management remained statistically insignificant and negligible influence on customers' loyalty in the cumulative model. However, all underpinnings had statistically significant influence on customers' loyalty as individual. Moreover, management commitment had mediating effect between relationship marketing and customers' loyalty. Depending on the findings, practical implications of this study is, in order to ensure loyalty among bank customers; bankers should build a better relationship marketing strategy. Therefore, banks competitiveness and profitability will depend on their ability to build strong relationship bonds with their customers continuously. Furthermore, future research directions were also suggested on this study.

Keywords: Relationship marketing, Trust, Commitment, Conflict Management, Communication, Gratitude, Management Commitment, Customers Loyalty.

$(\mathrm{cc}) \mathrm{BY}$

New articles in this journal are licensed under a Creative Commons Attribution 3.0 United States License.

\section{ULIS D-Sonle}

This journal is published by the University Library System of the University of Pittsburgh as part of its D-Scribe Digital Publishing Program, and is cosponsored by the University of Pittsburgh Press. 
The effect of relationship marketing on customers' loyalty (Evidence from Zemen Bank)

\section{Cherinet Boke Chakiso}

\section{Introduction}

\subsection{Background of the Study}

It is clear that customer is the only source of the companies' present profit and future growth. And also creating loyal customers is at the heart of every business (Keller and Kotler, 2012). Customers are central to all marketing activities all over the world. Success and in turn profit is not unthinkable without customers. Moreover, companies incur millions of dollars to attract customers and make them loyal. With the intense competition and increasing globalization of the financial markets, building customer loyalty has become a critical strategy for most financial institutions. The banking industry must develop strong relationships with their customers in order to compete successfully in the competitive retail banking environment (Zhang, 2009).

Clow and Kurtz, (2003) stated that banks profitability is closely related with customer's retention. They also claimed that, customer defection costs companies millions of dollars each year in lost revenue. In addition to lost revenue, defectors normally spread negative word of mouth communication which can influence other customers to purchase elsewhere. The longer a bank can retain a customer, the greater revenue and cost savings from that customer. Customer loyalty is an important factor that contributes to an organization's earning and profits. Loyal customers normally establish stable relationship with an organization compared to non loyal customers. Customer loyalty can contribute to an increase in a firm's revenue, reduce customer defection rate and develop new business through positive word of mouth advertising (Zeithaml and Bitner, 2003). Thus, at the end of the day, the bank's assets are not only primarily registered on the balance sheet, but also related to the fact that customers have been successfully retained.

In recent years, there has been a refocusing of marketing away from customer acquisition to that of customer retention. If the company is intended to benefit from retaining customers, customers also seek benefit from giving their loyalty to the company (Mudie and Pirrie, 2006). To achieve all the above mentioned goals of customer loyalty, firms devised a new strategy known as relationship marketing (Mudie et al, 2006). Several authors defined relationship marketing (RM) in different ways. To touch a few, Morgan and Hunt (1994), conceptualized relationship marketing as, "all marketing activities directed toward establishing, developing, and maintaining successful relational exchanges". On the other hand, Mudie et al, (2006), defined RM as „," ...Relationship marketing is a philosophy of doing business, strategic orientation that focuses on keeping and improving current customers rather than acquiring new customers".". This definition encompasses the planned action of a given organization to focus on building relationship with the existing customers than acquiring new ones. However, it is not to mean that a company which adopts relationship marketing strategy doesn't want to acquire customers. This new philosophy of marketing idea was first seen on marketing literature on 1983 (Parvatiyar and Sheth, 2000). After its idea of conception by berry in 1983, relationship marketing got the attention of several researchers. However, still now the field is growing in attention and underpinnings which can contribute for relationship building. Beginners may think it as only retention marketing. However, its goal is far from retention marketing (Mudie et al, 2006).

Well managed organizations work hard to develop relationships with desirable customers and to grow the volumes of business that they conduct. Several studies are revealing the importance of relationship marketing than traditional or transactional marketing, because it may cost a firm five to six times as much to attract a new customer as it does to retain an existing one. In addition, common wisdom suggests that long-term customers have the strongest and highest-paying relationships (Palmatier, 2008).

The new paradigm has several debating studies and still now there is no conceptually agreed definition and boundary about relationship marketing (Parvatiyar et al, 2000). The traditional marketing approach advocates the marketing mix principles and the quest for market share dominance through mass marketing techniques and focus on new customer acquisition. This approach has guided managers for decades, implementing their marketing strategies. Several studies developed the trust, commitment, conflict handling and a few studies also raised empathy, and gratitude as building blocks of relationship marketing 
(Anabila et al., 2012; Ndubisi, 2005; Ndubisi and Madu, 2009; Parvatiyar and Sheth, 2000; Morgan and Hunt, 1994; Kaur et al., 2012). This study focused on these variables as relationship marketing dimensions from customers'perspective and their effect on customers'loyalty by considering Zemen Bank as a case study.

\subsection{Statement of the Problem}

Service sector is leading GDP of the current trajectory economy of Ethiopia followed by agriculture and industry with $45.5 \%, 41.6 \%$, and 12.9 percent respectively (Development Bank of Ethiopia Report, 2012). Gilmore, (2003) noted that like many businesses today, financial services take place in an ever-changing context. Similarly, currently in Ethiopia, we are observing financial institutions especially in banking industry. One evidence is that out of 19 (nineteen) currently operating retail banks in Ethiopia, 9 (nine) of them are inaugurated and started working since 2008 (National bank of Ethiopia Report, 2012). This implies that almost half of the total banks in Ethiopia established in the last four and half years. These enormous increases in banks create an opportunity for the customers to choose the banks they want. As a result, fewer new customers are being pursued by an increasing number of service providers. Under those circumstances, firm's resources must be devoted to present customers, making them satisfied, loyal and returning clients.

As the financial marketplace becomes more dynamic and competitive, banks also need to focus on retaining existing clients through effective relationship marketing. In this context, the benefits of long-term retention of existing customers, such as increased profitability, reduced costs in relation to the individual customer and word of mouth referrals from satisfied customers, become important (Gilmore, 2003). Retaining customers requires careful and creative work and planning which satisfies customers. Service becomes more efficient when employees learn about what customers expect and how best to meet customer needs (Clow and Kurtz, 2003). Although, zero defections should be the goal of all organizations, in reality, it probably will not be achieved. It requires finding out switching factors, calculation of customers life time value (Clow et al, 2003), customers loyalty rate, and building lasting consumer relationship management (Kotler P. et al., 1999). Due to the above mentioned reasons, it is imperative to apply the modern paradigm shift in marketing called relationship marketing. Grönroos (1994) pointed out that relationship building and management are a vital corner stone for service industries. This is achieved by a mutual exchange and fulfillment of promises. Such relationships are usually but not necessarily long-term. Establishing a relationship with a customer can be divided in to two parts:
To attract the customer and to build relationship with that customer so that the economic goals of that relationship are achieved (Grönroos, 1994). It is not a time to market in a transactional basis. As stated above, since the field of relationship marketing is new as recent innovation in the field of marketing literature, there are no in-depth studies conducted especially in developing economies like Ethiopia. So, the aim of this study is to investigate the relationship marketing dimensions such as trust, commitment, conflict handling, communication, and gratitude of Zemen Bank, in order to assess whether these dimensions have had the intended strengthening effect on customers'loyalty. For better investigation of the study, the following questions were raised:

- Which selected relationship marketing dimensions affect customers'loyalty?

- To what extent relationship marketing had influence on customers'loyalty?

- Does management commitment have mediating effect on customers'loyalty?

\subsection{Objectives of the Study}

\subsubsection{General Objective}

The general objective of this study is to investigate the influence of relationship marketing dimensions on customers'loyalty.

\subsubsection{Specific Objectives}

The study has the following specific objectives:

- To measure the association between relationship marketing dimensions and customers loyalty.

- To assess the individual and cumulative effects of relationship marketing dimensions on customers loyalty.

- To point out the most and least important RM dimensions which have stronger influence on customers'loyalty.

\section{$1.4 \quad$ Research Hypothesis}

H1: Trust has a significant and positive effect on customers'loyalty.

$\mathrm{H} 2$ : Commitment has a significant and positive effect on customers'loyalty.

H3: Conflict handling has a significant and positive effect on customers'loyalty.

H4: Communication has a significant and positive effect on customers'loyalty.

H5: Gratitude has a significant and positive effect on customers'loyalty. 
H6: Relationship marketing dimensions as a cumulative have a significant and positive effect on customers' loyalty.

\subsection{Definition of Key Terms}

Relationship marketing is a philosophy of doing business, a strategic orientation that focuses on keeping and improving current customers rather than on acquiring new customers (Zeithaml and Bitner, 2003).

Trust is partners'confidence in an exchange partners reliability and integrity (Morgan and Hunt, 1994).

Commitment is an enduring desire to maintain a valued relationship (Morgan and Hunt, 1994).

Conflict is the overall level of disagreement between exchange partners (Palmatier, 2008).

Communication is the amount, frequency, and quality of information shared between exchange parties (Palmatier, 2008).

Gratitude is the emotional appreciation for benefits received, accompanied by a desire to reciprocate (Palmatier et.al, 2009).

A reciprocity norm is internalized patterns of behaviors and feelings that regulate the balance of obligations between two exchange partners.

Customer loyalty is a buyer's overall attachment or deep commitment to a product, service, brand, or organization (Oliver, 1999).

\subsection{Methodology of the Study}

\subsubsection{Sampling Techniques}

Sample is a part or subset of a population taken to be representative of the population as a whole (John Williams, 2004). The sample was drawn from bank customers to determine the effect of relationship marketing dimensions on customers'loyalty. After a short interview with vice chairman of domestic banking transactions of Zemen Bank, he responded that recently (as of February, 2013), Zemen bank has around 10,000 registered and known customers who are benefiting from different services of the company. Among them the data were collected from 200 customer respondents using the sample determination method developed by Carvalho (1984), as cited by Ahmed Kelil (2005), irrespective of their banking purpose, gender, occupation, income or age.

\subsubsection{Sources of Data and Data Collection}

Depending on objectives and research questions of the study; primary, secondary, and tertiary sources of data were used. The secondary data were collected from annual reports of organizations. On the other hand, tertiary data were collected from books, journal articles, full research papers, conference papers, and internet which discuss the theoretical framework of relationship marketing dimensions such as trust, commitment, conflict handling, communication, and gratitude, for the dependent variable customers' loyalty. Primary data were used to grasp current information from customers through survey questionnaire and semi-structure interview from assistant branch manager of domestic banking operations of Zemen bank. The survey questionnaire contains two parts. Part one describes the demographic profile of the respondents including gender, age range, education level, occupation, monthly income, duration they maintained Zemen bank account, and whether they have bank account other than Zemen bank and the reason if they have. The second part contains some descriptive questions under each underpinning dimensions of relationship marketing. In this part a number of questions were asked which can represent the construct. Trust dimension consists 7 questions that are adopted from Ndubisi and Wah, (2005). The second dimension contains 6 questions which were adopted from Ndubisi \& Wah (2005). Similarly, under third dimension which is conflict management, there were 7 questions which are adopted from Ndubisi \& Wah (2005). The fourth communication dimension comprises 6 questions which were adopted from Tahir and Abidin (2011), Shifera Bekela (2011) and developed by the researcher. The fifth dimension which is gratitude is comprised of 4 questions which were adopted from Palmatier et.al, (2009). The mediating variablemanagement commitment dimension consists 5 questions which were adopted from Tahir and Abidin (2011) and the researcher. Lastly, the dependent variable-customers loyalty is comprised of 8 questions which were adopted from Ndubisi and Wah (2005).

The survey questionnaire in part two is developed with a five point Likert scale format ranging from (strongly disagree to strongly agree). The values assigned for Likert scale were $1=$ Strongly Disagree, 2=Disagree, 3=Neutral, 4=Agree, and 5=Strongly Agree. In addition, questions for semi-structured interview were adopted from Shifera Bekele (2011), and developed by the researcher which can explain the intention and experience in relationship marketing and customers' loyalty. 
Table 1: Summary of questionnaire and its sources

\begin{tabular}{|l|l|l|l|}
\hline No. & Dimension & $\begin{array}{l}\text { Number } \\
\text { of items }\end{array}$ & Source/s/ \\
\hline $\mathbf{1}$ & Trust & 7 & $\begin{array}{l}\text { Ndubisi and Wah, } \\
(2005)\end{array}$ \\
\hline $\mathbf{2}$ & Commitment & 6 & $\begin{array}{l}\text { Ndubisi and Wah, } \\
(2005)\end{array}$ \\
\hline $\mathbf{3}$ & $\begin{array}{l}\text { Conflict } \\
\text { management }\end{array}$ & 7 & $\begin{array}{l}\text { Ndubisi and Wah, } \\
(2005)\end{array}$ \\
\hline $\mathbf{4}$ & Communication & 6 & $\begin{array}{l}\text { Tahir and Abidin } \\
(2011), \quad \text { Shifera } \\
\text { Bekela (2011), the } \\
\text { researcher }\end{array}$ \\
\hline $\mathbf{5}$ & Gratitude & 4 & $\begin{array}{l}\text { Palmatier et.al, } \\
(2009)\end{array}$ \\
\hline $\mathbf{6}$ & $\begin{array}{l}\text { Management } \\
\text { commitment }\end{array}$ & 5 & $\begin{array}{l}\text { Tahir and Abidin } \\
(2011) \text { and the } \\
\text { researcher }\end{array}$ \\
\hline $\mathbf{7}$ & $\begin{array}{l}\text { Customers } \\
\text { loyalty }\end{array}$ & 8 & $\begin{array}{l}\text { Ndubisi and Wah } \\
(2005)\end{array}$ \\
\hline Total & & $\mathbf{4 3}$ & \\
\hline
\end{tabular}

\subsubsection{Procedures of Data Collection}

The survey questionnaires were distributed for customers of the company inside the guest room when they came to get the service. Otherwise, it is difficult to identify customers from non-customers. The data were collected from customers who were awaiting the service. Before distributing the questionnaire, the researcher checked whether they maintained Zemen Bank account or not. They qualify to complete the questionnaire if they maintained Zemen Bank account. Since there is no any criteria to differentiate one customer from another and the researcher expected that any results gained from the respondents cannot cause substantial difference, the researcher used convenience sampling technique.

\subsubsection{Reliability Test}

Bhattacherjee (2012) defined reliability as the degree to which the measure of a construct is consistent or dependable. Reliability implies consistency, but not accuracy. Cohen et al. (2007) stated that alternative measure of reliability as internal consistency is the Cronbach alpha, frequently referred to as the alpha coefficient of reliability, or simply the alpha. The Cronbach alpha provides a coefficient of inter-item correlations, that is, the correlation of each item with the sum of all the other relevant items, and is useful for multi-item scales. In this study, Cronbach's Alpha is used to measure the internal consistency of the items used. George and Mallery (2003) provides the following rules of thumb: >0.9-Excellent, $>0.8$-Good, >0.7-Acceptable, >0.6-Questionable, >0.5Poor, and <0.5-Unacceptable (as cited in Gleam and Rosemary, 2003).

Table 2: Reliability Analysis: Cronbach's Alpha Value

\begin{tabular}{|l|l|l|}
\hline \multicolumn{1}{|c|}{ Dimensions } & Items & Cronbach's Alpha \\
\hline Trust & 7 & 0.756 \\
\hline Commitment & 6 & 0.840 \\
\hline Conflict management & 7 & 0.825 \\
\hline Communication & 6 & 0.798 \\
\hline Gratitude & 4 & 0.883 \\
\hline Management commitment & 5 & 0.788 \\
\hline Customers' loyalty & 8 & 0.853 \\
\hline \multicolumn{1}{|c|}{ Overall score } & 43 & 0.942 \\
\hline
\end{tabular}

Source: survey finding, (2013)

Based on the suggestion proposed by Guielford (1965) cited by Taleghani et al., (2011), the higher the Cronbach ${ }^{\text {ee }} \mathrm{s}$ alpha value, the higher the internal consistency is. If a value was higher than 0.70 , then it showed that the reliability of measurement was high. The above Table 2 shows that the value of the Cronbach's alpha ranges from 0.756 to 0.942 . This indicates a good acceptable internal consistency of the items in the scale for this study.

\subsubsection{Methods of Data Analysis}

After data are collected, it should be entered on a spreadsheet, database, text file, or directly into a statistical program like SPSS (Bhattacherjee, 2012). In this study, data were entered on a popular software package of SPSS 16.0 software version. All quantitative analyses results were the output of SPSS 16.0 software version. Depending on the collected data and the objectives, research questions, and hypothesis; descriptive and inferential statistical techniques were used.

\subsubsection{Descriptive Statistics}

From descriptive statistics, frequencies with their respective percentages in a simplified tabulated format were used to discuss demographic profile of the respondents. Those variables were analyzed using descriptive statistics of frequency and the mean was presented and summarized by using tables and analyzed and interpreted with simplified statements with tables and percentages followed by discussions. Mean is perhaps the 
most widely used and reported measure of central tendency (Marczyk, 2005). In addition, cross-tabulation was used to present the relationship between gender and bank account variety; and income and bank account variety. On the other hand, the results of semi-structured interview questions were analyzed qualitatively through narrative analysis.

\subsubsection{Inferential Statistics}

In contrast to the above descriptive analysis for part one on the survey questionnaire; the second part contains some five-point Likert scale questions under each underpinning of relationship marketing, mediating variable of management commitment and for customers'loyalty. The relationship between independent variable relationship marketing (trust, commitment, conflict handling, communication, and gratitude) and the mediating effect of management commitment between relationship marketing and customers'loyalty, and the dependent variable customers'loyalty were analyzed using correlation and regression analysis.

\subsubsection{Correlation Analysis}

Field (2007) suggested that before conducting any correlation analysis, it is essential to plot a scatter plot to look at the general trend of the data. Depending on this suggestion, the researcher did draw scatter plot to look the general trend of the data. That shows whether the independent and dependent variable has positive or negative slope or in turn positive or negative relationship. Correlations are perhaps the most basic and most useful measure of association between two or more variables. Expressed in a single number called a correlation coefficient $(r)$, correlations provide information about the direction of the relationship (either positive or negative) and the intensity of the relationship $(-1.0$ to +1.0$)$. Furthermore, tests of correlations will provide information on whether the correlation is statistically significant (Marczyk, 2005). Correlation coefficients range from -1.0 to +1.0 . The sign of the coefficient represents the direction of the relationship. In general, correlations of .01 to .30 are considered weak, correlations of .30 to .70 are considered moderate, correlations of .70 to .90 are considered strong, and correlations of .90 to 1.00 are considered very strong. Importantly, these are only rough guidelines. A number of other factors, such as sample size, need to be considered when interpreting correlations.

The Bivariate Correlations procedure computes the pairwise associations for a set of variables and displays the results in a matrix. It is useful for determining the strength and direction of the association between two scale or ordinal variables. The Pearson correlation coefficient measures the linear association between two scale variables (Marczyk, 2005).

In this study, Pearson correlation coefficient is used to measure the strength of the association between relationship marketing dimensions and customer loyalty.

\subsubsection{Regression Analysis}

Like correlations, statistical regression examines the association or relationship between variables. Unlike with correlations, however, the primary purpose of regression is prediction (Marczyk, 2005). Due to this, regression analysis is used to know by how much the independent variable i.e. relationship marketing explains or influences the dependent variable which is customer loyalty. Both simple and multiple regressions were used in this study. In simple regression, we attempt to predict the dependent variable with a single independent variable. In multiple regressions, we may use any number of independent variables to predict the dependent variable (Marczyk et al, 2005). In this study, simple regression is used to approve or disapprove hypotheses 1 up to 5; while, multiple regression was used to approve or disapprove hypothesis number 6 . In both of the types, statistical significance was given due care at $\mathrm{p}$ value of 0.05 .

\subsubsection{Multicollinearity}

If there is a high degree of correlation between independent variables, we have a problem of what is commonly described as the problem of multicollinearity Kothari, C.R. (2004). If Collinearity is discovered, (e.g. if correlation coefficients between variables are higher than .80) then one can either remove one of the variables or create a new variable that combines the previous two that were highly inter-correlated (Cohen et al., 2007). Cohen et al. (2007) cited that, in SPSS, one can find multicollinearity by looking at Collinearity diagnostics in the Statistics command box, and in the Collinearity statistics one should look at the Tolerance'column on the output. He indicates that values will vary from 0 to 1 and the higher the value the less is the Collinearity, whereas a value close to 0 indicates that nearly all the variance in the variable is explained by the other variables in the model. Correspondingly, Muge Arslan, F. and Altuna, O.K., (2010) cited that VIF value above 10 and a tolerance value below 0.10 pose a multicollinearity problem. In this study, the result of collinearity statistics analysis shows variance inflation factors (VIF). Value ranges from 1.57 to 2.093 . Tolerance value ranges within the value of $0.478-0.637$. In 
this study, these values (both VIF and tolerance level) indicate that for this analysis, there is no serious multicollinearity problem.

\section{General Discussion and Implications}

The main aim of this study was to investigate the effect of relationship marketing on customers' loyalty. In this research, both practical (managerial) and theoretical implications were drawn. For this study, data were collected from 187 respondents and analyzed on two broad parts. The first part is demographic and general information pertaining to customer respondents. On this part, the first item was gender. Here majority of the respondents were males and on the case of age, also majority of the respondents were detected in the age range of 20-40 years which means Zemen Bank comprises more of young population which creates an opportunity for the future of deep relationship with the customer. In the same vein, most of the customers of Zemen Bank were educated. This is also an opportunity for Zemen Bank. If they do the intended services well, they will get a big advantage, since educated peoples cannot choose services providers blindly. On the case of income, majority of the respondents have monthly income above ETB 5000. However, even if the above opportunities are existent, there is one caveat that alerts Zemen Bank managers. This is that, majority of the respondents on this study replied that they had maintained bank account in more than one banks. So, there is no any guarantee to Zemen Bank to retain them. Simply, the customers have much experience in banking and they can simply shift if better strategies like relationship marketing and better customer service are provided elsewhere. When compared with females, male have the greater tendency in diversifying bank accounts. This tendency can also relatively relate with their loyalty to bank. Similarly, the finding of Ndubisi (2005) shows that, there is significant gender difference in the trust-loyalty relationship. The researcher underlined that women are significantly more loyal than men at higher levels of trust in the bank.

Palmatier (2008) synthesized that, increased customer loyalty represents one of the most anticipated outcomes of RM efforts. But loyalty can be defined and measured in a plethora of ways. Conversely, this study found that RM can influence customers' loyalty. In addition, there is a strong association between RM and customers' loyalty with $\mathrm{r}=0.80$.

The results of Chaman et al. (2013) conducted on both government and private banks indicate that, four RM relationship, bound marketing strategy have a significant and positive impact on the loyalty of customers and preference of impact of these variables has been done as communication management, conflict management, commitment and trust.

Correspondingly, the results of Ndubisi (2005) show that the four underpinnings identified on the study (namely trust, commitment, communication, and conflict handling) of relationship marketing are directly associated with customer loyalty.

Anibala et al. (2012) concluded that if a bank wants to achieve a high rate of customer loyalty, then RM has to be considered as a strategy. Similarly, this study also cautions banks to build a better RM strategy to make customers loyal.

Specifically, the results suggest that in order to build loyal customers, banks should build better reciprocity norm, because gratitude has the highest influencing effect on customers' loyalty. Palmatier (2009) affirmed that "allowing a consumer to reciprocate a feeling of gratitude converts a short-term emotion into a long-lasting relational norm". Understanding and managing gratitude and its role in building and maintaining reciprocity norms appears to play an important part in effective relationship marketing.

Baron et al. (2010) asserted that, negative word of mouth comments about banks take all the income and profits away. This is in line with the interview response of the manager which stated as "We know how much goodwill of Zemen Bank will be affected if a conflict left unresolved through negative word of mouth communication from the customer". Palmatier (2009), also pointed out that "People pay more attention to negatives than to positives in RM; even hard-won relationships can suffer great damage because of conflict". However, in this study, conflict management can influence customers' loyalty as individual effect. Contrariwise, conflict management had statistically insignificant and negligible influence on customers' loyalty when it is regressed as cumulative.

\section{Conclusions and Recommendations}

\subsection{Conclusions}

Baron et al., (2010) summarized that from a firm's perspective, Relationship Marketing is based on two arguments:

- It is more expensive to win a new customer than it is to retain an existing one.

- The longer the association, the more profitable the relationship for the firm. 
Whilst it would depend on the individual, it is claimed that getting a new customer is five to ten times more expensive than retaining one.

This research provides empirical evidence for the influence on customer loyalty of five underpinnings of relationship marketing: Trust, commitment, conflict handling, communication, and gratitude. RM constructs are identified from the literature, integrated in the proposed model, and linked with customers' loyalty. In addition, the mediating effect of top management commitment with RM and customers' loyalty are also investigated. This study tries to validate that, in Zemen Bank; relationship marketing underpinnings had effect on customers' loyalty. Overall, all relationship marketing underpinnings such as trust, commitment, conflict management, communication, and gratitude have positive and moderate relationship with customers' loyalty.

Moreover, when the RM underpinnings are linearly regressed, they had cause and effect relationship with customers' loyalty at statistically significant $\mathrm{p}<0.01$. However, when they are regressed as multiple, conflict management cannot predict customers' loyalty since pvalue is not less than 0.05 . This is an important finding for companies that need to emphasize the influence of RM constructs on customers, loyalty. On the other hand, as a mediating variable, top management commitment satisfied all the given conditions with statistical significance and criterion. Therefore, management commitment had the mediating effect between RM underpinnings and customers loyalty. Moreover, when evaluated in general, the factors that have the greatest impact on customers' loyalty are gratitude and commitment. Conflict management has a negligent and statistically insignificant positive effect.

After validation, among the 6 hypothesis developed, all of them are approved. An interesting finding revealed that, gratitude is the key influencer of customers' loyalty by preceding popular findings like commitment and trust in other several studies. However, Palmatier, et al. (2009), claimed that marketing research that neglects gratitude and focuses exclusively on trust and commitment may fail to capture the full effects of RM and may systematically underestimate the true return on investment of RM activities.

In addition, bankers should focus on developing gratitude by applying reciprocity norms (giving and receiving), because gratitude had strong correlation and prioritized effect on customers loyalty when compared to others.

\subsection{Recommendations}

As discussed earlier, Flambard-Ruaud (2005) stated that at the centre of the relationship marketing paradigm is the notion that makes existing clients essential for long-term profitability. Several researchers' agreed on the importance of RM as the influence of customers' loyalty. Every business organization is working for profit. So, retaining clients by developing relationships with them is crucial to establish and maintain a competitive advantage in the market. So, even if the data are collected from only Zemen Bank customers', the recommendation can be applicable for Ethiopian banking industry. This is also supported because majority of the customers have different banking experience.

There is also an important finding for companies which signals that they need to emphasize relationship marketing underpinnings especially for males, since males had high tendency of testing services of different banks when compared to females. With respect to income, bankers should carefully segment customers depending on their income and deposit and give due attention for customers' who have higher income since when compared to customers who have lower income, higher income customers had greater tendency to test services of different banks.

Specifically, Zemen Bank should focus on general points like branch variety. Majority of the customers underlined one branch strategy of Zemen Bank as the problem. Moreover, there are outlying questions whose means are too far from grand mean, which shows the relative neutrality than agreement on the questions. Those include (1. the bank is flexible when its services change; 2 . the bank shows attention to my financial needs, updates me about financial markets in time; 3 . the bank communicates the intended services in media that I can be informed 4 . ATM machines of the bank are available at necessary places; 4 . It would be difficult to change my beliefs about the bank 5. Even if close friends recommended another bank; my preference for this bank would not change). So, on all those points (i.e. flexibility, communication of updated information on time, selection of promotion media and location of ATMs are important.

By considering the loyalty impact on profit, bankers should build strong relationship strategies because all relationship marketing underpinnings such as trust, commitment, conflict management, communication, and gratitude have positive and moderate relationships with customers' loyalty. 
According to the results of this study, banks wishing to retain and develop loyal customers should be:

- Trustworthy enough for their customers, since there is a significant and positive relationship between trust and customers loyalty. That means the bank should be careful about security of customers' transactions and their promises should be reliable discharge obligations and fulfill promises should be clear.

- Committed for the service. This means, banks should make adjustments to suit customer needs, be flexible when services are changed, and work with customers for the continual relationship.

\$ Working hard to reduce the overall level of disagreement between bank and customers.

- Communicating timely and accurately since there is significant and positive relationship between communication and customers' loyalty. This means banks should communicate information like updated financial data, indicate how and where to complain, use a wide spectrum of communications like phone calls, e-mails, and personnel visits as well as discussions.

* Developing a better reciprocity norm with customers, because gratitude plays a vital role in making customers loyal, which can in turn leads to profitability.

Besides, management of the banks should be committed for overall activities of the bank since top management commitment had mediating effect between relationship marketing and customers' loyalty.

\subsection{Limitations and Future Research Directions}

Like most of the survey studies, this study also has some limitations. Firstly, the study is limited to only Zemen Bank; so, a larger empirical study would be useful to replicate the results in the banking as well as other services. In addition, this research focused on banking services only; so, further research in other sectors may be necessary before generalization can be made on the entire service industry.

\section{REFERENCES}

Achour, M. Said, N.P. \& Boerhannueddin, A. (2009). Customer Loyalty: the case of mobile phone users in Universiti utara Malaysia, Unpublished material.

Ahmed Kelil, (2010). Employees' perception towards compensation and benefit policy: the case of some selected Government higher education institutions in Addis Ababa, Addis Ababa university, MBA thesis.

Ahmed, R. \& Buttle, F. (2001). Customer retention: a potentially potent marketing management strategy, Journal of Strategic Marketing 9, P 29-45

Anabila, P Narteh, B. Tweneboah-Koduah, E. (2012). Relationship Marketing Practices and Customer Loyalty: Evidence from the Banking Industry in Ghana. European Journal of Business and Management, Vol 4, No.13

Annual Report of Zemen Bank, (2012).

Aryan Hellas Limited (2005). Relationship

Marketing: Understanding and

Implementing the Concept. IBRH,

Athens. 
Ballantyne, D. Christopher, M. and Payne, A (2002), Relationship marketing: Creating Stakeholder Value; ButterworthHeinemann, Oxford, Britain.

Ballantyne, D. Christopher, M. and Payne, A. (2003). Relationship marketing: looking back, looking forward. Marketing Theory Articles, Volume 3(1): 159-166, www.sagepublications.com

Bekezela Ncube, (2009). Basic Information about Ethiopia.

Bhattacherjee, A. (2012). Social Science Research: Principles, Methods, and Practices, (2nd edition). The Global Text Project

Brahmbhatt M. (2008). An Assessment of Service Quality in Banks. Vol.2, Issue 4, Page no.37-41.

Brito, C. (2008). Relationship Marketing: From Its Origins to the Current Streams of Research. FEP Working Paper; University De Porto.

Christopher Lovelock and Lauren Wright (2006). Principles of service marketing and management.

Chung Lo S., (2012). A Study of Relationship Marketing on Customer Satisfaction. Journal of Social Sciences 8 (1): 91-94
Clow K.E. and Kurtz L.,(2003). Service Marketing, Operation, Management and Strategy. (second edition)

Cohen, L. Manion, L. and Morrison, K., (2007). Research Methods in Education. (6th edition), Routledge Taylir \& Francis publications Group, London and New York.

Creswell J.W (2003). Research DesignQualitative, Quantitative, and mixed methods approaches. (2nd edition),

Customer Loyalty Programs, (2011).

Darley W.K, and Blankson C, (2008). African culture and business markets: implications for marketing practices. Journal of Business \& Industrial Marketing 23/6, 374-383, Emerald Group Publishing Limited

Dawkins, R. (2008) Microsoft ${ }^{\circledR}$ Encarta ${ }^{\circledR} 2009$ [DVD]. Redmond, WA: Microsoft Corporation.

Development Bank of Ethiopia report, (May, 2012).

Dongmei Zhang (2009). Customer Switching Behaviour in the Chinese Retail Banking Industry. Research thesis, Lincoln University, Canterbury, New Zealand 
Dwyer, F. R., Schurr, P.H., \& Oh, S. (1987)

Developing Buyer-Seller Relationships. Journal of Marketing.

Field, A., (2005). Discovering Statistics Using SPSS. (2nd edition). Sage Publications Limited

Flambard-Ruaud, S. (2005). Relationship Marketing in Emerging Economies: Some Lessons for the Future. Vikalpa; volume 30 .

George and Mallery, (2003). Business Research Methods, Oxford University Press, P19

Gilmore, A. (2003). Services, Marketing and Management. SAGE Publications Ltd Grönroos, C. (1994). From Marketing Mix to Relationship Marketing: Towards a Paradigm Shift in Marketing. Management Decision, Vol. 32 No. 2, 1994, pp. 4-20. MCB University Press Limited.

Hanover Research, (June, 2011). Customer Loyalty Programs. 1101 Connecticut Ave. NW, Suite 300, Washington, DC $20036 \quad P \quad 202.756 .2971 \quad$ F www.hanoverresearch.com
Hennig-Thurau, H. \& Hansen, U. (2003).

Relationship Marketing - Some Reflections on the State-of-the-Art of the Relational Concept. University of Hanover.

Izah Mohd Tahir, I.M. \& Zulkifli, Z. (2011). A Preliminary Analysis of CRM Practices among Banks from the Customers' Perspectives. Journal of Public Administration and Governance . Vol. 1, No. 1.

Izquierdo, C.C. Cilla'n, J.G. \& Gutie'rrez, S.M. (2005). The impact of customer relationship marketing on the firm performance: a Spanish case. Journal of Services Marketing, Volume 19, p.234244, Emerald Group Publishing Limited

John Williams, (2004). Marketing Research and Information. Elsevier Ltd, Great Britain

Kanagal, N. (2009). Role of Relationship Marketing in Competitive Marketing Strategy. Journal of Management and Marketing Research. Indian Institute of Management, Bangalore 
Kaur G., Sharma R.D., and Mahajan N., (2012).

Exploring customer switching intentions through relationship marketing paradigm. International Journal of Bank Marketing Vol. 30 No. 4, pp. 280-302, Emerald Group Publishing Limited.

Kidane Assefa, (2012). Relationship Marketing in the Hotel Industry: The Nexus between Concepts and Practices (A case of Ghion Hotel, Addis Ababa Branch, Ethiopia). Unplished MA Project. Addis Ababa University.

Kothari, C.R. (2004). Research Methodology Methods and Techniques. (2nd edition). New Age International Publishers, India.

Kotler, P. \& Keller K.L., (2012). Marketing Management. (14th edition). Pearson Education, Inc., publishing as Prentice Hall, One Lake Street, Upper Saddle River, New Jersey 07458

Kotler, P. and Keller, K.L. (2006). Marketing Management (12th edition). Pearson Education, Inc., Upper Saddle River, New Jersey
Liu, M.T. Chu, R. Wong, I.A. Zúñiga, M.A. Meng, Y. \& Pang, C. (2012). Exploring the relationship among affective loyalty, perceived benefits, attitude, and intention to use co-branded products. Asia Pacific Journal of Marketing and Logistics, Emerald Group Publishing Limited.

Marczyk, G. DeMatteo, D. Festinger, D. (2005). Essentials of Research Design and Methodology. John Wiley \& Sons, Inc., Hoboken, New Jersey.

Marshall, N.W. (2010). Commitment, Loyalty and Customer Lifetime Value: Investigating The Relationships Among Key Determinants. Journal of Business \& Economics Research -. Volume 8, No. 8.

Morgan, R. \& Hunt, S. (1994). The CommitmentTrust Theory of Relationship Marketing. Journal of Marketing; Vol. 58, p20-38

Mosavi, S.A. and Ghaedi, M. (2012). A survey on the relationships between customer satisfaction, image, trust and customer advocacy behavior. African Journal of Business Management Vol. 6(8), pp. 2897-2910 
Muge Arslan, F. and Altuna, O.K. (2010). The effect of brand extensions on product brand image. Journal of Product \& Brand Management 19/3 (2010) 170-180. Emerald Group Publishing Limited.

Mudie, P. and Pirrie, A. (2006). Services marketing management. (Third edition). Published by Elsevier Ltd.

National bank of Ethiopia Report, 2012.

Ndubisi, N. O. and Wah, C.K. (2005). Factorial and Discriminant analysis of the underpinnings of relationship marketing and customer satisfaction. International Journal of Bank Marketing, vol. 23, No. 7, pp. 542-557.

Ndubisi, N.O. \& Madu, C.N. (2009). The association of gender to firm-customer relationship. International Journal of Quality \& Reliability Management. Vol. 26 No. 3, 2009 pp. 283-301, Emerald Group Publishing Limited

Ndubisi, N.O. (2005). Effect of gender on customer loyalty: a relationship marketing approach. Marketing Intelligence \& Planning Vol. 24 No. 1, 2006 pp. 48-61 Emerald Group Publishing Limited
Oliver, R. L. (1999). Whence Consumer Loyalty? (Special Edition). Journal of Marketing, 63(5): $33-44$.

Palmatier R.W., (2008). Relationship Marketing. Published by Marketing Science Institute, 1000 Massachusetts Ave., Cambridge, MA 02138, USA.

Palmatier, R.W. Jarvis, C.B. Bechkoff, J.R. \& Kardes, F.R. (2009). The Role of Customer Gratitude in Relationship Marketing. Journal of Marketing Vol. 73. American Marketing Association

Parvatyar A. and Jagdish, N.S (1999). Hand book of Relationship Marketing. Thousand Oaks, CA.

Parvatyar, A. and Jagdish, N.S (2001). Customer Relationship Management: Emerging Practice, Process, and Discipline. Journal of Economic and Social Research 1-34

Peter Lok, John Crawford, (2001). Antecedents of organizational commitment and the mediating role of job satisfaction. Journal of Managerial Psychology, Vol. 16, pp. $594-613$ 
Pezeshki, V. Mousavi, A. and Rakowski, R.T. (2005). Profitability through Customer Relationship Marketing. Proceedings of the International Conference on Computer and Industrial Management, ICIM, October 29-30, Bangkok, Thailand.

Saiz, B.S. \& Pilorge, P. (2010). Understanding customer behavior in retail banking- the impact of credit crisis across Europe. Earnest and Young.

Shifera Bekele, (2011). The impact of relationship marketing on customer loyalty in banking industry, the case of bank of Abyssinia. Unpublished Master's Thesis. Addis Ababa University.

Sorce P., (2002). Relationship Marketing Strategy. Printing Industry Center at Rochester Institute of Technology.

Taleghani, M. Gilaninia, S., and Mousavian, S.J. (2011). The Role of Relationship Marketing in Customer Orientation Process in the Banking Industry with focus on Loyalty (Case Study: Banking Industry of Iran), International Journal of Business and Social Science Vol. 2 No. 19.
Tyler, K. and Stanley, E. (2007). The role of trust in financial services business relationships. Journal of Services Marketing. 21/5 (2007) 334-344, Emerald Group Publishing Limited

Zeithaml, V.A. and Bitner, M.J (2003). Service marketing: Integrating customer focus across the firm. (Third edition). Tata McGraw-Hill, India.

Zemen Bank - http://www.zemenbank.com/

Zulkifli, Z. \& Tahir, I.M. , (2011). A Preliminary Analysis of CRM Practices among Banks from the Customers' Perspectives. Journal of Public Administration and Governance. Vol. 1, No. 1 